\title{
Water quality evaluation of Al-Gharraf river by two water quality indices
}

\author{
Salam Hussein Ewaid ${ }^{1}$
}

Received: 14 August 2016/Accepted: 15 December 2016/Published online: 26 December 2016

(c) The Author(s) 2016. This article is published with open access at Springerlink.com

\begin{abstract}
Water quality of Al-Gharraf river, the largest branch of Tigris River south of Iraq, was evaluated by the National Sanitation Foundation Water Quality Index (NFS WQI) and the Heavy Metal Pollution Index (HPI) depending on 13 physical, chemical, and biological parameters of water quality measured monthly at ten stations on the river during 2015. The NSF-WQI range obtained for the sampling sites was 61-70 indicating a medium water quality. The HPI value was 98.6 slightly below the critical value for drinking water of 100 , and the water quality in the upstream stations is better than downstream due to decrease in water and the accumulation of contaminants along the river. This study explains the significance of applying the water quality indices that show the aggregate impact of ecological factors in charge of water pollution of surface water and which permits translation of the monitoring data to assist the decision makers.
\end{abstract}

Keywords NSF-WQI - HPI · Water quality index · Al-Gharraf river

\section{Introduction}

Water is a substance of great environmental importance. It is described as 'the liquid of life' and has two measurements that are firmly connected, amount and quality. Water quality is a network of physical, chemical, and biological variables affect each other (Akanda et al. 2007).

Salam Hussein Ewaid

salamalhelali@yahoo.com

1 Technical Institute of Shatra, Southern Technical University, Shatra, Iraq
In Iraq like other countries, rivers pollution levels are no longer within the safe limits for consumption, and the distribution and availability of water does not coincide with the requirements. The decay of water quality became a serious threat beside the lack of effective monitoring network, especially in Al-Gharraf basin, which was characterized by a mainly agricultural land use of about 700,000 hectares (Saleh 2010; Al-Ansari 2011).

Iraqi rivers water is under growing threats because of the increasing of industrial and agricultural pollution, salinity, hardness, water to decrease caused by climate change (limited rains in the north), also the many dams which had been built in Turkey, Syria, Iran, and the bad planning used in irrigation (Al-Ansari 2013). Water Quality Indices (WQIs) is methods by which water quality information is condensed for reporting to the public in a reliable way (Abbasi and Abbasi 2012). WQIs are widely used to assess water quality and each WQI use a different collection of water quality parameters (Bharti and Katyal 2011). By comparing the monitored values with the regulatory standards, it combines data into a single number that describes the nature of the water source (Rai et al. 2012). There are many WQIs which had been developed and validated by researchers worldwide (Prasad and Kumari 2008; Reza and Singh 2010). The National Sanitation Foundation's Water Quality Index (NSF-WQI), the Canadian Council of Ministers of the Environment's Water Quality Index (CCME-WQI), the Oregon Water Quality Index (OWQI), and Heavy Metal Pollution Index (HPI) are well-known examples; the differences among WQIs are the statistical integration and interpretation of the resulting values (Alobaidy et al. 2010; Lumb et al. 2011; Abbasi and Abbasi 2012).

The aim of this research is to evaluate the water quality status of Al-Gharraf River based on NSF-WQI and HPI indices. 


\section{Materials and methods}

\section{The study area}

Al-Gharraf is the main branch of Tigris River; it flows from the right bank of Tigris at Al-Kut Dam to the Euphrates basin passing Wasit and Dhi-Qar governorates and ends in Al-Hammar marsh north of Nassyria City. Its maximum capacity, in the beginning, is about $622 \mathrm{~m}^{3} / \mathrm{s}$, with the length of about $230 \mathrm{~km}$, and the drainage area is $435,052 \times 106 \mathrm{~m}^{2}$. Fifty-two canals and 968 irrigation ditches branched from it and irrigate an area of 700,000 hectares (Al-Sahaf 1965; US Department of Agriculture 2009). The river geographical position is: longitude $45^{\circ} 47^{\prime} 25^{\prime \prime} \mathrm{E}$, and latitude $32^{\circ} 31^{\prime} 55^{\prime \prime} \mathrm{N}$ which gives the river valley semi-arid climate characteristics,

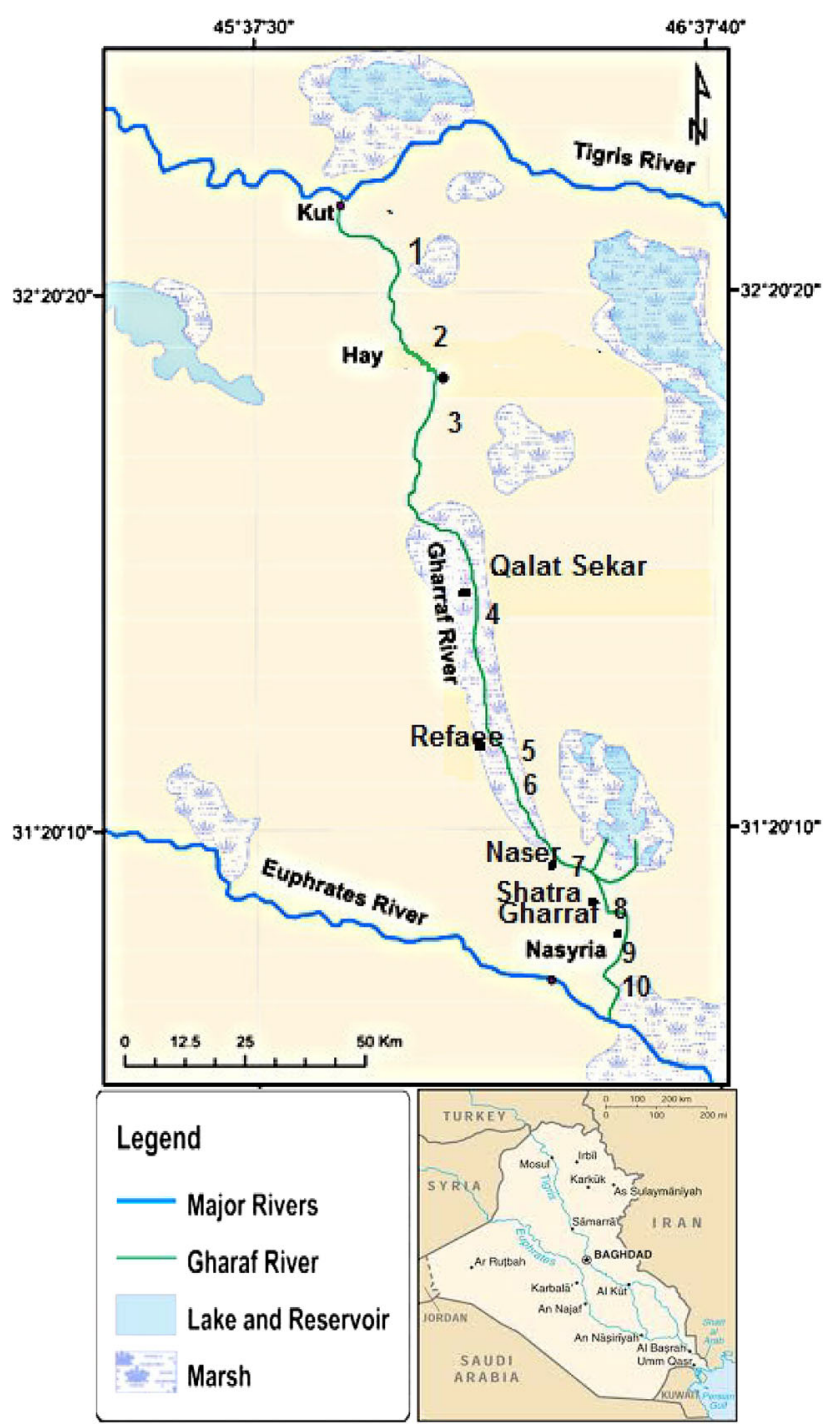

Fig. 1 Map of the study area and the sampling stations locations. Modified from (Al-Abadi 2014) such as high temperature in summer, low moisture, few annual rainfall of about $150 \mathrm{~mm}$, high rate of sun radiation, and high rate of evaporation (Saleh 2010; Atiaa 2015).

The river suffers from human and natural problems like reduction of water, the growth of plants, pollution, and accumulation of clay (Ewaid 2011). Ten sampling stations were chosen along the river (Fig. 1). The first two stations, in the beginning of the river, have the same features of the Tigris, with no cities and little pollution sources for $200 \mathrm{~km}$, there are many agricultural fields on both banks, but the third station is affected by domestic wastewater from Al-Hay town. The fourth-to-seventh stations have salt areas on the left side and agricultural fields on the right. The urban waste water from Qalaat Sekar, Rifai, and Nasr towns affect the river. The eighth-to-tenth stations begin near Al-Bada'a head regulator have low water level and narrow width, but they are important, because there are four refinery stations on the right side before Shatra town, which provide drinking water to Dhi-Qar and Basrah governorates. The urban waste water from Shatra and Gharraf towns affected the last two stations, Fig. 1.

\section{Water samples collection and analysis}

The physical, chemical, and microbiological parameters: biochemical oxygen demand (BOD), dissolved oxygen (DO), nitrates $\left(\mathrm{NO}_{3}\right)$, total phosphates $\left(\mathrm{PO}_{4}\right)$, temperature (T), turbidity (Tur.), total solids (TS), pH, fecal coliform (FC), and the four heavy metals ( $\mathrm{Cd}, \mathrm{Ni}, \mathrm{Pb}$, and $\mathrm{Zn}$ ) were determined by standard methods and procedures as presented in Table 1.

Water samples were taken monthly from the ten sampling stations during 2015 and analyzed in the laboratory of the Environmental Pollution Unit of the Shatra Technical Institute and the heavy metals were analyzed in The Central Organization for Standardizations and Quality Control, Baghdad.

Collection, stabilization, transportation, storage, and analysis of samples were done according to the standard methods in [American Public Health Association (APHA) 2012].

\section{The national sanitation foundation's water quality index (NSF-WQI)}

It is a scale with 100 points that represent the results from nine variables, such as $\mathrm{BOD}, \mathrm{DO}, \mathrm{NO}_{3}, \mathrm{PO}_{4}, \mathrm{~T}$, Tur., TS, $\mathrm{pH}$, and FC, it was developed by Brown et al. 1970 [Abbasi and Abbasi 2012; American Public Health Association (APHA) 2012]; the index calculator is available online: http://www.water-research.net/index.php/water-treatment/ water-monitoring/monitoring-the-quality-of-surfacewaters.

This index represents general water quality and does not perceive particular water use capacities. Some of the index parameters have different importance, so a weighted mean 
Table 1 Measurement methods for the water quality parameters

\begin{tabular}{|c|c|c|c|c|}
\hline & Parameters & Unit & Method & Site \\
\hline 1 & $\mathrm{DO}$ & $\mathrm{mg} / \mathrm{l}$ & Portable multi-meter 340i. WTW/Germany & In situ \\
\hline 2 & $\mathrm{pH}$ & & & \\
\hline 3 & Temperature & ${ }^{\circ} \mathrm{C}$ & & \\
\hline 4 & Turbidity & NTU & TURB 355 IR/T. Portable turbidity meter, WTW/Germany & In situ \\
\hline 5 & $\mathrm{FC}$ & $\mathrm{CFU} / 100 \mathrm{ml}$ & SM 9215, membrane filtration & Laboratory \\
\hline 6 & BOD & $\mathrm{mg} / \mathrm{l}$ & SM 5210, azide modification at $20^{\circ} \mathrm{C}(5 \mathrm{D})$ & Laboratory \\
\hline 7 & Total $\mathrm{PO}_{4}$ & $\mathrm{mg} / \mathrm{l}$ & SM 4500-P, spectrophotometric, molybdate-ascorbic acid method. & Laboratory \\
\hline 8 & Nitrate & $\mathrm{mg} / \mathrm{l}$ & Spectrophotometric, SM $4500 \mathrm{NO}_{3} \mathrm{E}$ cadmium reduction & Laboratory \\
\hline 9 & Total solids & $\mathrm{mg} / \mathrm{l}$ & SM 2540 , dried at $103-105^{\circ} \mathrm{C}$ & Laboratory \\
\hline 10 & Heavy metals $\mathrm{Cd}, \mathrm{Ni}, \mathrm{Pb}, \mathrm{Zn}$ & $\mu \mathrm{g} / 1$ & $\begin{array}{l}\text { Atomic absorption Phoenix-986 Spectrophotometer. Biotech Eng. } \\
\text { Management CO., LTD. (UK) }\end{array}$ & Laboratory \\
\hline
\end{tabular}

is useful to calculate the index, Table 2. The temperature change refers to the different in temperature between upstream and downstream control sites (Abbasi and Abbasi 2012; Rai et al. 2012).

The oxygen percent saturation $(\mathrm{Sa} \%)$ was calculated depending on the equation in (American Public Health Association (APHA) 2012). Where DO (mg/l at $100 \%$ saturation) $=8.73 \mathrm{mg} / \mathrm{l}$ :

$\mathrm{DO}($ Sa. $\%)=\frac{\text { Measured DO }(\mathrm{mg} / \mathrm{l})}{\mathrm{DO}(\mathrm{mg} / \mathrm{l} \text { at } 100 \% \text { saturation })} \times 100$.

The weighted score (Wi) must be multiplied by the subindex value $(\mathrm{Li})$ of the parameter obtained by the NSFWQI, then it will be summed by the index equation (Abbasi and Abbasi 2012).

$\mathrm{NSF} \mathrm{WQI}=\sum_{1=0}^{n} \mathrm{Wi} \times \mathrm{Li}$

where NSF-WQI is the score of the water quality index; Wi is the weighted score; and $\mathrm{Li}$ is the sub-index value (all calculated by the index calculator available online).

The number obtained from applying the index is classified in five scale categories as in Table 3 (USGS 2015; Brown et al. 1970).

Table 2 Weight scores of the nine NSF-WQI parameters

\begin{tabular}{ll}
\hline Parameters & Weighted mean \\
\hline $\mathrm{DO}$ & 0.17 \\
$\mathrm{FC}$ & 0.16 \\
$\mathrm{pH}$ & 0.11 \\
$\mathrm{BOD}$ & 0.11 \\
$\mathrm{~T}$ & 0.1 \\
$\mathrm{NO}_{3}$ & 0.1 \\
$\mathrm{PO}_{4}$ & 0.1 \\
$\mathrm{Tur}$. & 0.08 \\
$\mathrm{TS}$ & 0.07 \\
\hline
\end{tabular}

Table 3 NSF-WQI categories

\begin{tabular}{ll}
\hline Range & Quality \\
\hline $0-25$ & Very bad \\
$26-50$ & Bad \\
$51-70$ & Medium \\
$71-90$ & Good \\
$91-100$ & Excellent \\
\hline
\end{tabular}

\section{Heavy metal pollution index (HPI)}

It is a method that rates the total influence of a heavy metal and a composite influence of all metals on the nature of water and contamination (House and Ellis 1987). The metal weighted factor is equal to the inverse of the standard value and the weighted factors summation is less than one. Higher values of HPI indicate decayed water quality as for metals utilizing both the ideal and the standard values (Prasanna et al. 2012).

In this study, cadmium, nickel, lead, and zinc have been measured for the index utilizing which had been designed by Dede et al. (2013) and can be calculated by these two equations:

$\mathrm{Qi}=\sum_{1=1}^{n} \frac{\{\mathrm{Mi}(-) \mathrm{li}}{(\mathrm{Si}-\mathrm{Ii})} \times 100$

$\mathrm{HPI}=\frac{\sum_{1=1}^{n} \mathrm{WiQi}}{\sum_{1=1}^{n} \mathrm{Wi}}$

where Qi is the sub-index of the $i$ th metal, Wi is the unit weightage of $i$ th metal, $n$ is the number of metals included, Mi is the monitored value of the heavy metal, Ii is the ideal value, and $\mathrm{Si}$ is the standard value of the $i$ th metal ignoring the sign (-) which indicates the difference between the two values, and the maximum HPI threshold value is 100 for drinking water (Mohan et al. 1996; Prasad and Bose 2001). 


\section{Results and discussion}

\section{Water quality parameters}

Overall, annual water quality data of Al-Gharraf river at the ten stations during 2015 comparing with the World Health Organization standard (Edet and Offiong 2002), Iraqi standard for drinking water [World Health Organization (WHO) 2011], and with Iraqi standard for maintenance of rivers and public water (IQS 2009) are presented in Table 4.

$\mathrm{pH}$ is a scale used to quantify the acidity or alkalinity of water. Most aquatic creatures have a restricted $\mathrm{pH}$ range around 6-8 units [Ministry of Environment (MOEN) 1998]. The $\mathrm{pH}$ in this study ranged 7-7.9, within the Iraqi standard, and each station has almost the same $\mathrm{pH}$. River water tends to be alkaline, because the natural existence of the carbonates and bicarbonates, and that is typical for Iraqi rivers (Naubi et al. 2016).

DO is essential to aquatic life for respiration and most organisms have an ideal scope of DO. It maintains the effect of organic materials wastes by water self-purification (Al-Shujairi 2013). The results showed that the concentration of DO in Al-Gharraf river water rises in winter and decreases in summer and the ten stations have almost the same DO amount. In healthy water, DO must be $>4 \mathrm{mg} / \mathrm{l}$ (Prasad and Bose 2001), and the DO of the river is still in good criteria and ranged $6-10 \mathrm{mg} / \mathrm{l}$.

Temperature can decide the rate of biochemical responses in the aquatic ecosystem (Simon et al. 2011). Water temperature of $\mathrm{Al}$-Gharraf river ranges $17-33{ }^{\circ} \mathrm{C}$ during the year of the study and there was a slight difference among stations but large among seasons reflecting the weather condition of the area.

Turbidity is a measure of the water's absence of clarity. Turbid water decreases light infiltration, and affects photosynthesis and aquatic life. High total solid can raise water temperature, since solid materials get heat from daylight (Fulazzaky 2010). The upper part of the river is wide with the fast flow which makes the turbidity high compared to the downstream river by the range of 40-98 NTU and always it was out of all standards. The TS level fluctuated from 620 to $870 \mathrm{mg} / \mathrm{l}$ within the river water during the study and there was no difference among stations but among seasons. Water containing more than $500 \mathrm{mg} / \mathrm{l}$ of total dissolved solid is not comfortable for drinking water supply (Smitha and Shivashankar 2013).

Table 4 Annual mean water quality parameters values of Al-Gharraf river water

\begin{tabular}{|c|c|c|c|c|c|c|c|c|c|c|}
\hline & Edet and Offiong (2002) & $\begin{array}{l}\text { World Health Organization } \\
\text { (WHO) } 2011\end{array}$ & \multicolumn{2}{|c|}{ IQS 2009} & S. 1 & S. 2 & S. 3 & S. 4 & S. 5 & S. 6 \\
\hline $\mathrm{T}$ & - & - & \multicolumn{2}{|l|}{$<35$} & 24.5 & 23.8 & 24 & 24.5 & 24.2 & 23 \\
\hline $\mathrm{pH}$ & $8.2-8.8$ & $6.5-8.5$ & \multicolumn{2}{|l|}{$6-9.5$} & 7.4 & 7.3 & 7.5 & 7.4 & 7.2 & 7.55 \\
\hline $\mathrm{TS}$ & 500 & 1000 & \multicolumn{2}{|l|}{-} & 731 & 717 & 700 & 722 & 712 & 727 \\
\hline DO & 4 & - & \multicolumn{2}{|l|}{-} & 8.2 & 8.62 & 7.95 & 7.47 & 7.3 & 7.85 \\
\hline $\mathrm{Sa} \%$ & - & - & \multicolumn{2}{|l|}{-} & 97 & 95 & 95 & 90 & 85 & 93 \\
\hline Tur. & $<1.5$ & $<5$ & \multicolumn{2}{|l|}{-} & 81 & 78.3 & 75.3 & 73.3 & 68 & 68.3 \\
\hline $\mathrm{PO}_{4}$ & 0.2 & - & \multicolumn{2}{|l|}{3} & 0.13 & 0.27 & 0.2 & 0.23 & 0.3 & 0.44 \\
\hline $\mathrm{NO}_{3}$ & 10 & 50 & \multicolumn{2}{|l|}{50} & 4.1 & 3.85 & 4.5 & 4.5 & 4.7 & 4.55 \\
\hline BOD & 3 & - & \multicolumn{2}{|l|}{-} & 1.7 & 1.95 & 2.8 & 3.5 & 3.8 & 3.58 \\
\hline \multirow[t]{2}{*}{ FC } & 0 & - & - & & 520 & 527 & 652 & 510 & 660 & 587 \\
\hline & $\begin{array}{l}\text { Edet and Offiong (Edet } \\
\text { and Offiong 2002) }\end{array}$ & $\begin{array}{l}\text { World Health Organization } \\
\text { (WHO) } 2011\end{array}$ & IQS 2009 & S. 7 & S. 8 & S. 9 & S. 10 & Min. value & Max. & value \\
\hline $\mathrm{T}$ & - & - & $<35$ & 23.8 & 24 & 25.2 & 25.3 & 17 & 33 & \\
\hline $\mathrm{pH}$ & $8.2-8.8$ & $6.5-8.5$ & $6-9.5$ & 7.5 & 7.6 & 7.5 & 7.8 & 7 & 7.9 & \\
\hline TS & 500 & 1000 & - & 720 & 710 & 700 & 710 & 620 & 870 & \\
\hline DO & 4 & - & - & 6.83 & 6.98 & 7.12 & 7.4 & 6 & 10 & \\
\hline $\mathrm{Sa} \%$ & - & - & - & 83 & 95 & 85 & 85 & 75 & 110 & \\
\hline Tur. & $<1.5$ & $<5$ & - & 67 & 67.3 & 58.5 & 59 & 40 & 98 & \\
\hline $\mathrm{PO}_{4}$ & 0.2 & - & 3 & 0.59 & 0.56 & 0.6 & 0.32 & 0.1 & 0.66 & \\
\hline $\mathrm{NO}_{3}$ & 10 & 50 & 50 & 4.78 & 4.55 & 4.68 & 3.25 & 2.5 & 7.5 & \\
\hline BOD & 3 & - & - & 3.55 & 3.7 & 6.12 & 5.42 & 0.8 & 10.1 & \\
\hline $\mathrm{FC}$ & 0 & - & - & 652 & 660 & 795 & 828 & 115 & 1900 & \\
\hline
\end{tabular}

$T$ in ${ }^{\circ} \mathrm{C}, \mathrm{pH}$ in $\mathrm{pH}$ unit, $\mathrm{FC}$ in $\mathrm{CFU} / 100 \mathrm{ml}$, Tur. in NTU, and the rest in $\mathrm{mg} / \mathrm{l}$ 
Table 5 NSF-WQI values of Al-Gharraf river stations

\begin{tabular}{lll}
\hline Stations & NSF-WQI value & Class \\
\hline 1 & 70 & Medium \\
2 & 67 & Medium \\
3 & 67 & Medium \\
4 & 66 & Medium \\
5 & 64 & Medium \\
6 & 63 & Medium \\
7 & 61 & Medium \\
8 & 62 & Medium \\
9 & 60 & Medium \\
10 & 64 & Medium \\
\hline
\end{tabular}

BOD is the quantity of oxygen used by bacteria and fungi to break down water organic compounds during 5 days (Naubi et al. 2016). In Al-Gharraf River, it ranged from 0.8 to $10.1 \mathrm{mg} / \mathrm{l}$ and it was relatively low. The quality standard of WHO is $<3 \mathrm{mg} / \mathrm{l}$ (Edet and Offiong 2002); therefore, BOD of the first three stations reached the criteria, but at the last, seven stations did not, especially in summer and early autumn.

Nitrate is a key supplement for water plants and creatures to use nitrogen. Its source is domestic sewage, agricultural waste, and soil erosion (Ell 2008). Nitrate concentration in the study stations is relatively low and ranged $2.5-7.5 \mathrm{mg} / \mathrm{l}$. WHO quality standard for nitrate content must be $\leq 10 \mathrm{mg} / \mathrm{l}$, (Edet and Offiong 2002); in this manner, nitrate was inside the quality standard for drinking water and river water.

Phosphate is a key supplement for plants and creature's growth, but high phosphorus in water can increase eutrophication. Sewage, detergent, and fertilizers are basic sources (Viessman and Hammer 2005). Total phosphate concentration in Al-Gharraf River extended 0.1-0.66 mg/l. All out phosphate in every station was not much different and within Iraqi standard for rivers maintenance, but it was not meet the WHO quality standard of $0.2 \mathrm{mg} / \mathrm{l}$ (Edet and Offiong 2002).

Fecal coliform bacteria existence in water is an indicator of the sewage contamination and the possible presence of other pathogenic organisms; the results showed that the river water exceeds (do not meet) the water quality criteria for fecal coliform bacteria.

\section{Application of NSF-WQI}

In light of the application of NSF-WQI, the river has medium water quality according to the categories in Table 3 above, as presented in Table 5.

There are some parameters reaching out of the Iraqi standard for drinking water [World Health Organization (WHO) 2011], WHO for drinking water (Naubi et al. 2016), and Iraqi standard for rivers maintaining (IQS 2009); those parameters were temperature (in summer and early autumn), turbidity, total phosphate, BOD, and FC, Table 4. The NSF-WQI values ranged 61-70 demonstrated that the exercises of the general population had no huge negative impact on the water quality particularly on the upper part of the waterway and the nature of the water at each station was verging on same.

\section{Heavy metal contents}

The metals studied were: zinc which is as an essential for the metabolism in biota, lead which has no known function in biota, and nickel and cadmium which are micronutrients needed in a few organisms [Edet and Offiong 2002; Chemical Society of Ethiopia (CSE) 2008; World Health Organization (WHO) 1996; Agostino et al. 2009]. These four metals have been selected for their importance to the health and availability of laboratory testing capability. The annual mean of the dissolved four heavy metals in $\mu \mathrm{g} / \mathrm{l}$ was: Cd (0.32), Ni (2.25), Pb (20), and Zn (29.8), Table 6. These results showed that the average concentration of the four metals for the ten sites was within the permissible limit of WHO and Iraqi standard for drinking water and Iraqi standard for rivers and public water maintenance.

\section{Heavy metal pollution index application}

For calculating the HPI, $\mathrm{Cd}, \mathrm{Ni}, \mathrm{Pb}$, and $\mathrm{Zn}$ were used. The weightage (Wi) was taken as the inverse of $\mathrm{Si}$ which is the WHO standard for drinking water (Prasad and Bose 2001), Ii is the Iraqi standard (Edet and Offiong 2002), and $M$ is the measured value of metal concentration and all in $\mu \mathrm{g} / \mathrm{l}$.

Since the weightages given to $\mathrm{Ni}$ and $\mathrm{Zn}$ are very less, these metals do not contribute much to the evaluation of

Table 6 Annual concentration mean of the dissolved four heavy metals in filtered water of Al-Gharraf river by $\mu \mathrm{g} / \mathrm{l}$ unit

\begin{tabular}{lllllllllllllll}
\hline & $\begin{array}{l}\text { Prasad and Bose } \\
\text { (2001); Edet and } \\
\text { Offiong (2002) }\end{array}$ & S. 1 & S. 2 & S. 3 & S. 4 & S. 5 & S. 6 & S. 7 & S. 8 & S. 9 & S. 10 & Min & Max \\
\hline $\mathrm{Cd}$ & 3 & 0.03 & 0.32 & 0.4 & 0.42 & 0.4 & 0.33 & 0.17 & 0.25 & 0.3 & 0.37 & ND & 0.9 \\
$\mathrm{Ni}$ & 20 & 1.7 & 2.1 & 2 & 2.3 & 2 & 2.6 & 3.5 & 2.4 & 1.8 & 2.1 & ND & 4 \\
$\mathrm{~Pb}$ & 10 & 9 & 11 & 9 & 8 & 10 & 12 & 11.7 & 8 & 9.5 & 13 & 2.4 & 20 \\
$\mathrm{Zn}$ & 3000 & 29 & 31 & 32 & 37 & 33 & 25 & 14 & 22 & 35 & 40 & 12 & 48 \\
\hline & & & & & & & & & & & & & &
\end{tabular}


Table 7 Standards used for the HPI index computation

\begin{tabular}{llrrlll}
\hline $\mathrm{HM}$ & $\mathrm{M}$ & $\mathrm{Si}$ & $\mathrm{Ii}$ & Wi & Qi & Wi.Qi \\
\hline $\mathrm{Cd}$ & 0.32 & 5 & 3 & 0.3 & 40.2 \\
$\mathrm{Ni}$ & 2.25 & 70 & 20 & 10 & 0.014 & 0.1 \\
$\mathrm{~Pb}$ & 20 & 100 & 3000 & 0.000 & 0.497 \\
$\mathrm{Zn}$ & 29.8 & 5000 & & & 0.46 & 148.5 \\
\hline
\end{tabular}

$\sum \mathrm{Wi}=0.414$

$\sum \mathrm{Wi}$ Qi $=40.848$

HPI value $=98.6$

HPI of the river water, but $\mathrm{Pb}$ and $\mathrm{Cd}$ have been given high weightages and have much contribution, Table 7 .

The HPI value calculated by these standards and the two equations mentioned above for Al-Gharraf river water considering every one of the seasons and stations was 98.6 utilizing the mean concentrations, and there were little variations among sampling stations and seasons.

This HPI value is less than the maximum threshold value of 100 as proposed by Dede et al. (2013). This result indicates that the influence of the four studied metals on the river water quality is alarming because of the domestic sewage discharge, soil erosion, and some industrial activities while evaluating the HPI index.

The concentrations of the four heavy metals in AlGharraf river water at all stations were found to be low and within guideline levels recommended. Results of this study can serve as baseline environmental data benchmark for monitoring build-up of heavy metals in streams and rivers.

\section{Conclusions}

This study presents the advantages of using WQIs in evaluating the general quality of water and sums up numerous data in a single value. Al-Gharraf river water can be used for public consumption after the traditional treatment; however, the results reveal that the river is polluted by anthropogenic activities and the NFS WQI values were 61-70 indicating a medium water quality. Utilizing WQIs is more systematic and gives comparative evaluation of the water quality of sampling stations. It is also helpful for public to understand the quality of water and being a useful tool in the field of water quality administration.

Open Access This article is distributed under the terms of the Creative Commons Attribution 4.0 International License (http:// creativecommons.org/licenses/by/4.0/), which permits unrestricted use, distribution, and reproduction in any medium, provided you give appropriate credit to the original author(s) and the source, provide a link to the Creative Commons license, and indicate if changes were made.

\section{References}

Abbasi T, Abbasi SA (2012) Water quality indices. Elsevier, Amsterdam, p 384

Agostino MR, Marcella R, Giovanni C (2009) Cadmium adsorption on vermiculite, zeolite and pumice. J Env Manag 90:364-374

Akanda A, Freeman S, Placht M (2007) The Tigris-Euphrates River basin: mediating a path towards regional water stability. Al Nakhlah, (Spring Issue 1-12)

Al-Abadi AM (2014) Modeling of stage-discharge relationship for Gharraf River, southern Iraq using back propagation artificial neural networks, M5 decision trees, and Takagi-Sugeno inference system technique: a comparative study. Appl Water Sci. doi:10.1007/s13201-014-0258-7

Al-Ansari NS (2011) Toward prudent management of water resources in Iraq. J Adv Sci Eng Res 1:53-67

Al-Ansari NA (2013) Management of water resources in Iraq: perspectives and prognoses. J Eng 5:667-684

Alobaidy AHMJ, Abid HS, Maulood BK (2010) Application of water quality index for assessment of Dokan lake ecosystem, Iraq. J Water Res Prot 2:792-798

Al-Sahaf M (1965) Iraq hydrology and hydrometry. Extended abstract of Cand Sci (Geogr) Thesis. Mosk. Gos. Univ, Moscow

Al-Shujairi SH (2013) Develop and apply water quality index to evaluate water quality of Tigris and Euphrates Rivers in Iraq. Int J Mod Eng Res (IJMER) 3(4):2119

American Public Health Association (APHA) (2012) Standard methods for the examination of water and wastewater, 27th edn. Washington, DC

Atiaa AM (2015) Modeling of stage-discharge relationship for Gharraf river, southern Iraq by using data driven techniques. Water Util J 9:31-46

Bharti N, Katyal D (2011) Water quality indices used for surface water vulnerability assessment. Int $\mathrm{J}$ Ecol Environ Sci 2(1):154-173

Brown RM, McClelland NI, Deininger RA, Tozer RG (1970) Water quality index-do we dare? Water Sewage Works 117(10):339-343

Chemical Society of Ethiopia (CSE) (2008) A comparative study of the phosphate levels in some surface and water bodies of Swaziland. Bull Chem Soc Ethiop 22(2):197-206

Dede OT, Telci IT, Aral MM (2013) The use of water quality index models for the evaluation of surface water quality: a case study for Kirmir basin, Ankara, Turkey. Water Qual Expo Health $5: 41-56$

Edet AE, Offiong OE (2002) Evaluation of water quality pollution indices for heavy metal contamination monitoring. A study case from Akpabuyo-Odukpani area, Lower Cross River Basin (Southeastern Nigeria). GeoJ 57:295-304 
Ell MJ (2008) Total suspended solids (TSS). In: NDDO Health (ed), North Dakota, USA

Ewaid SH (2011) Heavy metals in water, sediment and some biota of Al-Gharraf river, south of Iraq, M.Sc. Thesis, University of Baghdad, Baghdad

Fulazzaky MA (2010) Water quality evaluation system to assess the status and the suitability of the Citarum river water to different uses. Env Monit Assess 168(1-4):669-684

House MA, Ellis JB (1987) The development of water quality indices for operational management. Water Sci Technol 19(9):145-154

IQS (2009) Iraqi Quality Standards. Ministry of Planning, Central Agency for Standardization and Quality Control, Standard No, (417) 2nd modification, drinking water, $\mathrm{p} 9$

Lumb A, Sharma TC, Bibeault JF (2011) A review of genesis and evolution of water quality index (WQI) directions. Water Qual Expo Health 3:11-24

Ministry of Environment (MOEN) (1998) System maintenance of river and public water pollution in Iraq. http://www.moen.gov.iq. Accessed Apr 2016

Mohan SV, Nithila P, Reddy SJ (1996) Estimation of heavy metal in drinking water and development of heavy metal pollution index. J Environ Sci Health 31:283-289

Naubi I, Zardari NH, Shirazi SM, Ibrahim NFB, Baloo L (2016) Effectiveness of water quality index for monitoring Malaysian river water quality. Pol J Environ Stud 25(1):231-239

Prasad B, Bose JM (2001) Evaluation of the heavy metal pollution index for surface and spring water near a limestone mining area of the lower Himalayas. Environ Geo 41:183-188

Prasad B, Kumari S (2008) Heavy metal pollution index of ground water of an abandoned open mine filled with fly ash. Mine Water Environ 27(4):265-267

Prasanna MV, Praveena SM, Nagarajan R, Elayaraja A (2012) Evaluation of water quality pollution indices for heavy metal monitoring: a case study from Curtin Lake Miri city, East Malaysia. Environ Earth Sci 67:1987-2001

Reza R, Singh G (2010) Heavy metal contamination and its indexing approach for river water. Int J Environ Sci Tech 7(4):785-792

Rai RK, Upadhyay A, Ojha CSP, Singh VP (2012) The Yamuna River basin. Water Science and Technology Library 66:307-356

Saleh DK (2010) Stream gage descriptions and stream flow statistics for sites in the Tigris and Euphrates Rivers Basins, Iraq. USGS data series 540:146

Simon FX, Penru Y, Guastalli AR, Lorens J, Baig S (2011) Improvement of the analysis of the biochemical oxygen demand (BOD) of Mediterranean seawater by seeding control. Talanta 85(1):527-532

Smitha AD, Shivashankar P (2013) Physico-chemical analysis of the freshwater at river Kapila, Nanjangudu industrial area, Mysore, India. J Env Sci 2(8):59-65

US Department of Agriculture (2009) Fact sheet-USDA at work for agriculture in Iraq. http://www.fas.usda.gov/icd/iraq/ Iraqfactsheet.asp. Accessed June 2016

USGS (2015) National field manual for the collection of water quality data, techniques of water resources, book 9 , handbooks for water resources investigations, pp 1539

Viessman W, Hammer MJ (2005) Water supply and pollution control, 7th edn. The University of Michigan, Pearson Prentice Hall, USA

World Health Organization (WHO) (1996) Zinc in drinking-water background, WHO guidelines for drinking water quality, vol 2, 2nd edn. WHO, Geneva

World Health Organization (WHO) (2011) Guidelines for drinking water quality, 4th edn. http://www.who.int/water. Accessed Jan 2016 